\title{
EXPERIMENTAL INVESTIGATION OF THERMAL PERFORMANCE OF PETROL ENGINE USING FUEL CATALYST
}

\author{
Sagar.A.Patil ${ }^{1}$, Priyanka.V.Kadam ${ }^{2}$, Mangesh.S.Yeolekar ${ }^{3}$, Sandip.B.Sonawane ${ }^{4}$ \\ ${ }^{1}$ Student (Final Year), Department of Mechanical Engineering, GES's R.H.S. COE, Nashik, Maharashtra, India \\ ${ }^{2}$ Student (Final Year), Department of Mechanical Engineering, GES's R.H.S. COE, Nashik, Maharashtra, India \\ ${ }^{3}$ Student (Final Year), Department of Mechanical Engineering, GES's R.H.S. COE, Nashik, Maharashtra, India \\ ${ }^{4}$ Assistant Professor, Department of Mechanical Engineering, GES's R.H.S. COE, Nashik, Maharashtra, India
}

\begin{abstract}
As everyone is aware, the price of fuel keeps on fluctuating from time to time, therefore, oil conservation and saving on fuel is everybody's concern. We all know that extensive use of petroleum products has left our environment highly polluted, leading to various health hazards, ozone layer depletion and global warming. Therefore, it has become inevitable to have some solution at our disposal so as to conserve fuel, reduce pollution and save our environment. One way to conserve fuel, reduce pollution and save our environment is the use of fuel catalyst. Fuel catalyst is a mixture of compounds which helps in efficient burning of fuel. We have carried out a test on SI engine with plain petrol and mixture of plain petrol and fuel catalyst. Work also reports evaluation of thermal performance of plain petrol with $0.38 \%$ and $0.79 \%$ by mass of fuel catalyst and compared with that of plain petrol. Also fuel properties relevant to the fuel were determined for the various concentrations of fuel catalyst, in a mixture of plain petrol and fuel catalyst and also for plain petrol. In this paper it is shown that higher concentration of fuel catalyst in plain petrol leads to effective combustion of supplied fuel which results in lower air fuel ratio for same speed. There is improvement in the thermal performance of engine due to blending of fuel catalyst with plain petrol. Also effect of fuel catalyst on the environment is noted by the measurement of exhaust emission of plain petrol and mixture of plain petrol \& fuel catalyst.
\end{abstract}

Keywords: Plain petrol, Fuel catalyst, Thermal performance, Brake thermal efficiency. $* * *$

\section{INTRODUCTION}

Rapidly increase in fuel prices and traffic pollution along with scarcity of petroleum based fuel has accelerated an interest for improvement in the existing engine systems. But most of the times due to complex manufacturing techniques as well as practical constrain changes is not that much feasible. One of the best ways for improvement is conjunction of fuel catalyst with plain petrol. Petrol engine transforms chemical energy of supplied fuel into thermal energy and uses this energy to produce mechanical work. This study evaluated performance of plain petrol with various concentrations of fuel catalyst and compared with the performance obtained by using plain petrol on the same engine.

\subsection{Objective}

Objective of this study is to assess thermal performance of petrol engine using petrol as a fuel. And compare it with, that to be obtained from petrol with fuel catalyst. Thermal performance is to be evaluated at different load conditions and speed. Also, to evaluate the maximum thermal efficiency using fuel catalyst along with plain petrol and to check the suitability of fuel catalyst from environmental point of view. The optimum concentration of fuel catalyst in plain petrol is also to be found out.

\subsection{Fuel Catalyst}

The main constituents of fuel catalyst are ferrocene, a cleaning agent and binding agent. Ferrocene is antiknocking agent which prevents the knocking of petrol even if the temperature of the system increases. Cleaning agent assures that the carbon deposition in the system decreases. And the binding agent holds all the constituents together. Fuel catalyst has Octane boosting property. Besides this fuel catalyst contains a fuel treatment component as a part of its composition, prevents corrosion of fuel inlet system and combustion chamber. Fuel catalyst is a powerful fuel system cleaner and also cleans the combustion chambers. The fuel system has a job of delivering proper fuel and air mixture to the engine, to give you the performance you need. Use of multifunctional catalyst will lead to better fuel conservation and emission control due to proper combustion of supplied fuel [1].

\section{PERFORMANCE OF PETROL ENGINE}

\subsection{Engine Parameters}

- $\quad$ Brake Power (B.P): It is the power available at output shaft of an engine. 
B. $P(k W)=\frac{2 \Pi N T}{60000}$

- Brake Specific Fuel Consumption (BSFC): The amount of fuel required to be supplied to an engine to develop $1 \mathrm{~kW}$ power per hour.

$\operatorname{BSFC}(\mathrm{kg} / \mathrm{kWh})=\frac{\text { Fuel flow in } \mathrm{kg} / \mathrm{hr}}{\text { Brake power }}$

- Brake thermal efficiency $\left(\eta_{\text {втн }}\right)$ : Thermal efficiency is the indication of conversion of heat supplied into work energy and thermal efficiency based on B.P. is termed as brake thermal efficiency.

$$
\eta_{\mathrm{BTH}}=\frac{\text { Brake power }}{\text { Fuel flow }(\mathrm{kg} / \mathrm{s}) \times \mathrm{GCV} \text { of fuel }(\mathrm{kJ} / \mathrm{kg})}
$$

\subsection{Experimental Set Up}

The set up consists of four cylinders, four stokes, and (MPFI) engine connected to hydraulic dynamometer for different loading conditions. It is provided with essential components for measurement of engine parameters. The set up includes fuel tank, fuel measuring unit, load indicator, and speed indicator. Rotameters are provided for water flow measurement of cooling water circulation. Provision is also made to measure exhaust emissions directly with the help of gas analyzer and printer. The set up enables study of engine performance for brake power, indicated power, brake thermal efficiency, brake specific fuel consumption and heat balance.

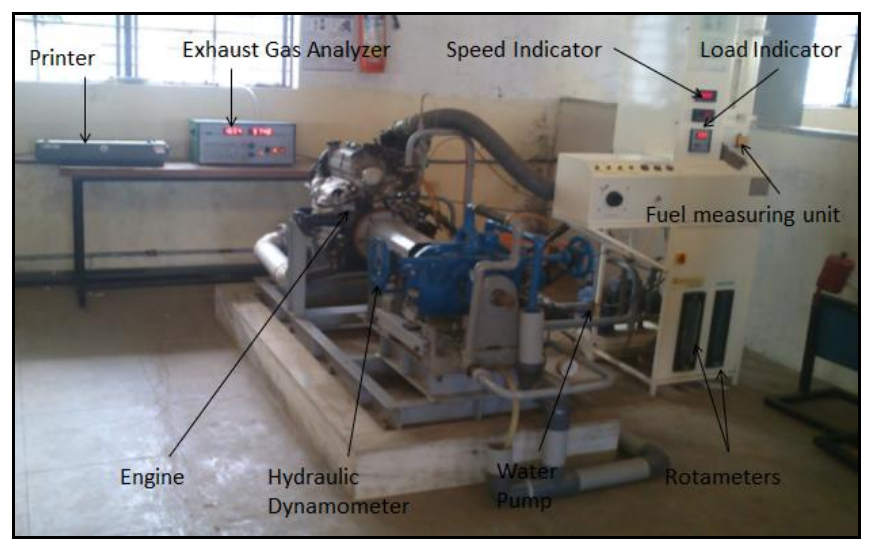

Fig -1: Diagram of set up used

\subsection{Engine and Set Up Details}

Table -1: Experimental set up details

\begin{tabular}{|c|c|}
\hline Parameter & Details \\
\hline Rated Power & $47.7 \mathrm{~kW} \mathrm{@} \mathrm{6200} \mathrm{RPM}$ \\
\hline Rated Torque & 84 NM @ 3500 RPM \\
\hline Cooling Type & Water Cooled \\
\hline
\end{tabular}

\begin{tabular}{|c|c|}
\hline Compression Ratio & $9.2: 1$ \\
\hline Stroke Length & $72 \mathrm{~mm}$ \\
\hline Bore Diameter & $68.5 \mathrm{~mm}$ \\
\hline Dynamometer & Hydraulic (Radius $=0.2 \mathrm{~m}$ ) \\
\hline Load Cell & Beam Type-S beam, $0-50 \mathrm{Kg}$ \\
\hline Calorimeter Used & Pipe In Pipe \\
\hline
\end{tabular}

\subsection{Experimental Procedure}

Experimental investigation is carried out in three different phases,
i. Sample preparation
ii. Measurement of fuel properties
iii. Performance tests

\subsubsection{Sample Preparation}

Sample is resultant fuel obtained due to different concentrations of fuel catalyst in plain petrol. Various samples used during investigation are as follows,

- Sample 1 (Plain petrol)

- Sample 2 (Plain petrol $+0.38 \%$ by mass of fuel catalyst)

- Sample 3 (Plain petrol $+0.79 \%$ by mass of fuel catalyst )

\subsubsection{Measurement of Fuel Properties}

Gross Calorific Value (GCV) and density are the fuel properties vary with concentrations of fuel catalyst in plain petrol.

Table -2: Variation in GCV

\begin{tabular}{|c|c|}
\hline Samples & GCV(KJ/kg) \\
\hline Sample 1 & 45541.41 \\
\hline Sample 2 & 39949.61 \\
\hline Sample 3 & 37032.86 \\
\hline
\end{tabular}

Table -3: Variation in Density

\begin{tabular}{|c|c|}
\hline Samples & Density $\left(\mathbf{k g} / \mathbf{m}^{\mathbf{3}}\right)$ \\
\hline Sample 1 & 754 \\
\hline Sample 2 & 763.2 \\
\hline Sample 3 & 764.6 \\
\hline
\end{tabular}

\subsubsection{Procedure for Performance Test}

Ensure cooling water circulation for dynamometer, engine cooling and calorimeter. Also check lubrication level to avoid over heating of engine. Required fuel sample on which test is to be conducted is filled in the fuel tank. Start the set up and 
run the engine at no load for 4-5 minutes. Starting from no load running condition load is gradually increased. Maximum applied load should not be greater than $80 \%$ of maximum load capacity. Variations in speed as well as emissions with respect to gradual load increment are noted.

\section{RESULTS AND DISCUSSION}

The performance tests were conducted on different fuel samples. From the performance tests engine brake power, BSFC, brake thermal efficiency and exhaust emissions (HC and $\mathrm{CO}$ ) with respect to different loads and speeds were obtained as discussed below.

\subsection{Brake Thermal Efficiency}

Chart -1 shows variation of brake thermal efficiency versus different loads.

- There is no considerable improvement in brake thermal efficiency at low loads. Brake thermal efficiency increases with increase in fuel catalyst concentration at higher loads. Considerable enhancement can be seen at higher loads.

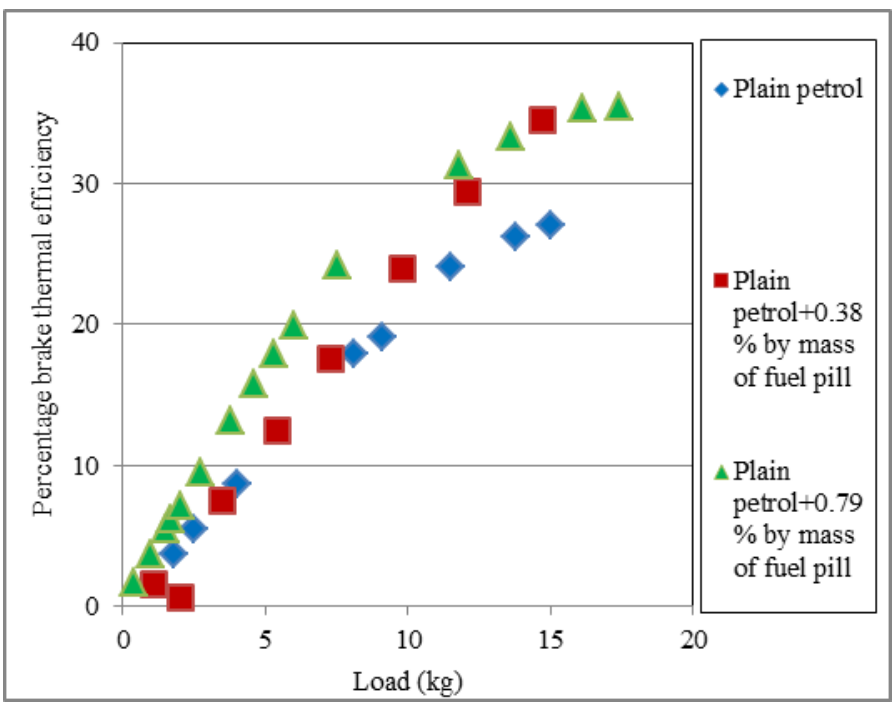

Chart -1: Variation in percentage brake thermal efficiency with increasing load

- In comparison to plain petrol, it is found that thermal efficiency is increased by approximately $30 \%$ and $35 \%$ when concentration of fuel catalyst is $0.38 \%$ and $0.79 \%$ by mass respectively. Fuel catalyst assists fuel to burn more completely in the combustion chamber. Hence for a given load and specific fuel consumption, petrol and fuel catalyst mixture produces more brake power. Hence petrol and fuel catalyst mixture as a fuel shows considerable enhancement in thermal efficiency, particularly at higher loads.

\subsection{Brake Specific Fuel Consumption (BSFC)}

Chart-2 and Chart-3 shows comparison between BSFC of various samples with respect to different loads and speed conditions respectively.

- $\quad$ Brake Specific Fuel Consumption (BSFC) decreases as load on engine increases. This decreasing nature is obtained due to efficient burning of the fuel, as the fuel catalyst has octane number enhancement properties, the fuel burns more effectively. Also octane number of the catalyst must be higher than plain petrol as it acts as a boosting agent.

- Brake Specific Fuel Consumption decreases on adding fuel catalyst. In comparison to plain petrol, at $15 \mathrm{~kg}$ load it decreases by $10.3 \%$ for sample 2 and $6.8 \%$ for sample 3 at speed ranges between 1050 1200 RPM.

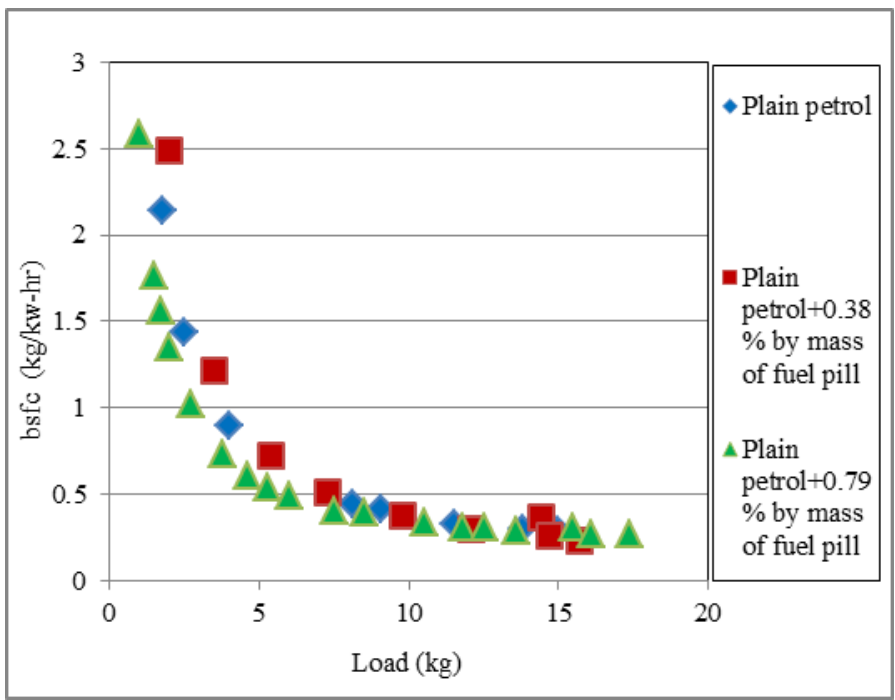

Chart -2: Variation of brake specific fuel consumption with increasing load

- Effect of increasing speed on Brake Specific Fuel Consumption is represented in Chart-3. It has been observed that BSFC drastically increases at higher speed which is quite obvious as at higher speeds the losses due to friction increases and volumetric efficiency decreases.

- In comparison with plain petrol the mixture of petrol and fuel catalyst achieve high speed earlier, as we can observe from the graphs, a range of $1300 \mathrm{rpm}$ is attended sooner by the mixture of petrol and fuel catalyst than that by plain petrol. 


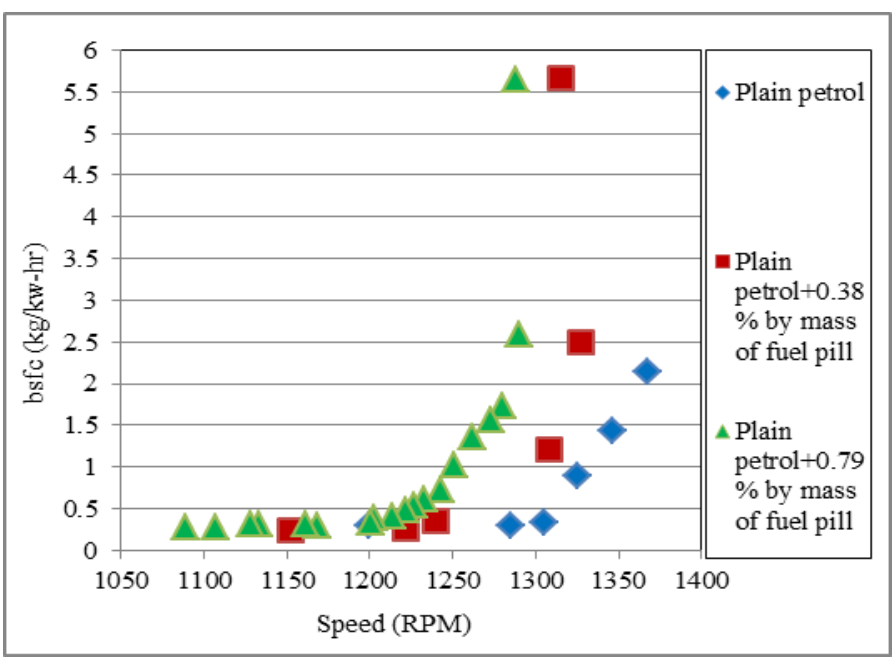

Chart -3: Variation of brake specific fuel consumption with increasing speed

\subsection{Brake Power}

From Chart-4 it could be observed that engine power decreases at higher speeds because frictional losses are more at higher speed.

- Besides, comparison with engine power generated by using plain petrol, engine is able to produce same power at lower speeds when concentration of fuel catalyst is more. Hence, it can generate more torque at low speeds. This will increase mileage of engine and ultimately overall life of an engine.

- There is no considerable improvement in brake power for sample 2 but for sample 3, at $15 \mathrm{Kg}$ load, B.P increases by $5.42 \%$ compared to plain petrol.

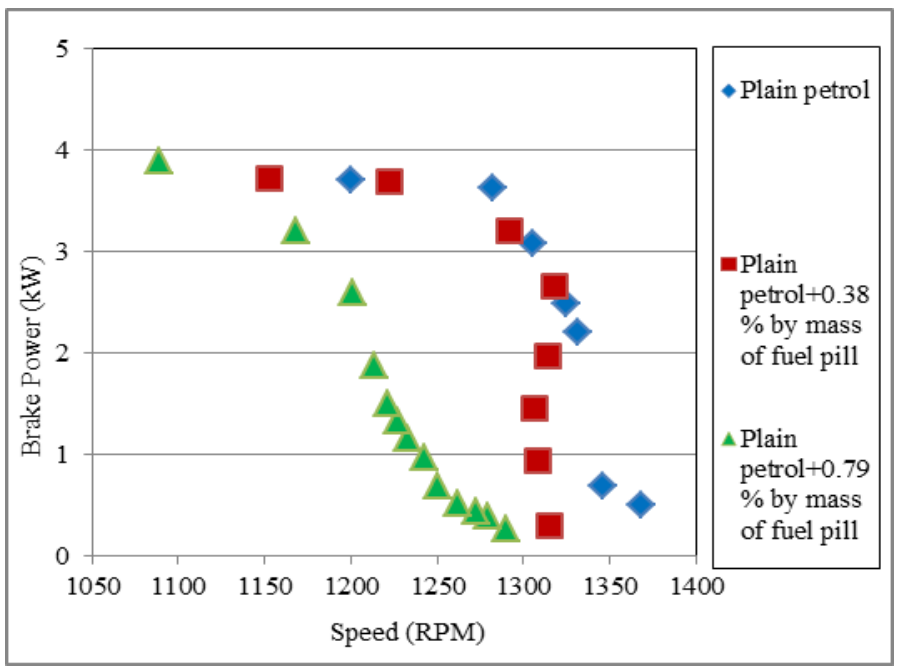

Chart -4: Variation of brake specific power with increasing speed

\subsection{Exhaust Emissions}

Chart-5 and Chart-6 shows comparison of exhaust gases between various samples with respect to different load and speed conditions respectively.

- It was observed that percentage of exhaust gases tends to increase with increase in concentration of fuel catalyst.

- Though there is effective combustion of supplied fuel due to presence of fuel catalyst but $\mathrm{CO}$ and $\mathrm{HC}$ emissions were found to be increased. This is due to supply of rich mixture for combustion.

- Emission of CO ranges between 1.4 to $2.1 \%$ while, emission of $\mathrm{HC}$ ranges between $550 \mathrm{ppm}$ to 1100 ppm.

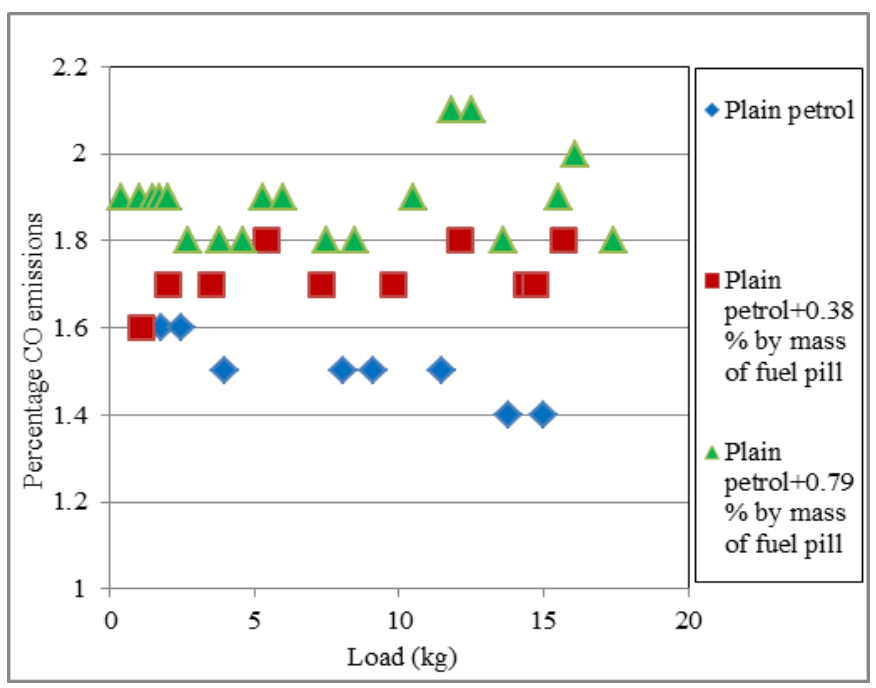

Chart -5: Variation of $\mathrm{CO}$ emissions with increasing load

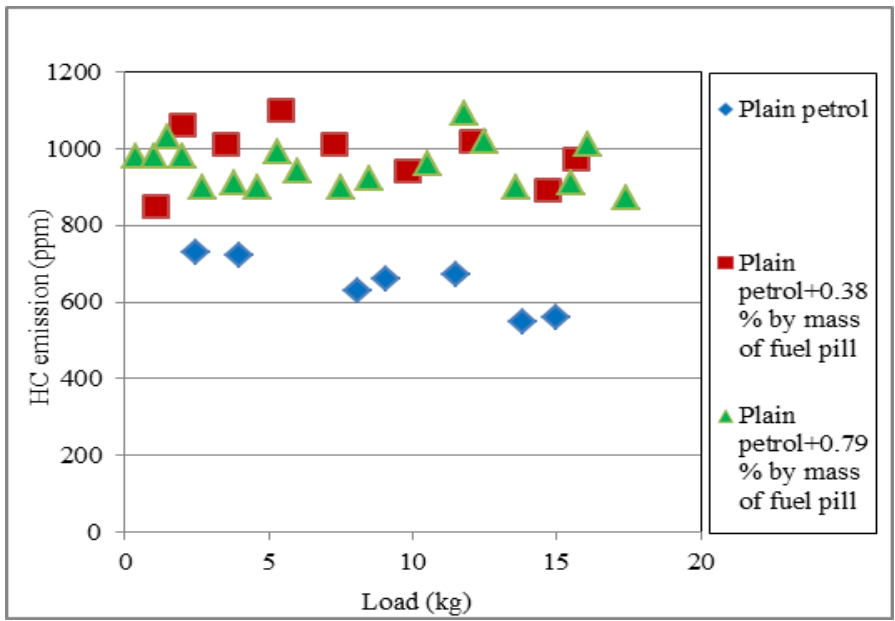

Chart -6: Variation of HC emissions with increasing load 


\section{CONCLUSIONS}

Addition of catalyst in petrol increases the quality of petrol in terms of combustible properties; it also helps in reduction of carbon deposits in fuel delivery system.

Based on the experiments the following conclusions were drawn,

- Brake thermal efficiency increases with the increasing fuel catalyst concentration in the mixture of fuel catalyst and petrol. Enhancement observed in brake thermal efficiency is approximately $30 \%$ and $35 \%$ when concentration of fuel catalyst is $0.38 \%$ and $0.79 \%$ by mass respectively.

- Increase in brake power of the engine reflects that the BSFC should also increase, but from the experimental results it is observed that as the concentration of fuel catalyst (in a mixture of petrol and fuel catalyst) increases BSFC is reduced by a $10 \%$ and $6.9 \%$ when concentration of fuel catalyst is $0.38 \%$ and $0.79 \%$ by mass respectively.

- It is also observed that using fuel catalyst engine can produce more torque at relatively low speed thus this ultimately benefits in better engine life.

- Fuel properties such as resultant density and gross calorific value of the mixture are directly proportional to concentration of fuel catalyst.

- There must be reduction in emission of exhaust gases due to use of fuel catalyst but from the obtained results emission of $\mathrm{HC}$ and $\mathrm{CO}$ increases, it indicates that rich mixture is supplied to the engine. It is necessary to supply more quantity of air for better combustion of petrol and fuel catalysts mixture. Due to practical limitations in our laboratory we are unable to vary the mass flow rate of air externally.

\section{REFERENCES}

[1] Fuel catalyst www.mp6ty.com/product.aspx

[2] M.V.S Murali Krishna and K Kishor "Performance of copper coated spark ignition engine with methanol blended gasoline with catalytic converter"Vol.67, July 2008, pp.543-548, Journal of Scientific and Industrial Research.

[3] R.K.Tyagi and Ravi Ranjan "Effect of hydrogen and gasoline fuel blend on the performance of SI engine" Vol. 4(7), November 2013, pp. 125-130, Journal of Petroleum Technology and Alternative Fuels.

[4] M.L.Mathur and R.P.Sharma "A Book on Internal Combustion Engines" Dhanpat Rai Publication.

[5] M.A.Kalam, H.H.Masjuki and I.I.Yaacob, "Evaluation of exhaust emission reduction of a retrofitted bi-fuel spark ignition engine" Journal of energy \& environment, volume 5, May 2006.

[6] N. Seshaiah, "Efficiency and exhaust gas analysis of variable compression ratio spark ignition fuelled with alternative fuels", International journal of energy and environment, volume 1, 2010, pp.861-870.

[7] Jitendra Kumar, Dhananjay Trivedi, Prakash Mahara, Ravi Butola, "Performance study of ethanol blended gasoline fuel in spark ignition engine" International organization of scientific research, journal of mechanical and civil engineering, volume 7, August 2013.

[8] L.Bromberg, D.R.Cohn, "Effective octane and efficiency advantages of direct injection alcohol engines" MIT labortary for energy and the environment ,January 2008.

[9] Hitesh.B.Bisen and Y.R.Suple, ${ }^{\text {ecee }}$ Experimental Investigation of exhaust emissions of four stroke SI engine using direct injection LPG and its analysis", International journal of modern engineering research, volume 3, October 2013, pp.2600-2605.

\section{BIOGRAPHIES}

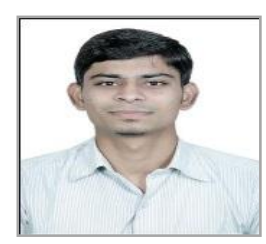

Sagar Ambadas Patil ${ }^{1}$, Pursuing Final Year in Bachelor of Mechanical Engineering degree from GES's R.H.S.C.O.E, Nashik, under the affiliation of University of Pune, Maharashtra, India

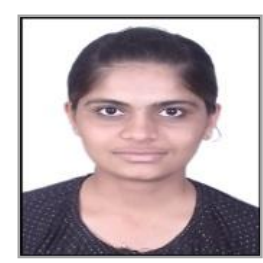

Priyanka Valu Kadam², Pursuing Final Year in Bachelor of Mechanical Engineering degree from GES's R.H.S.C.O.E, Nashik, under the affiliation of University of Pune, Maharashtra, India

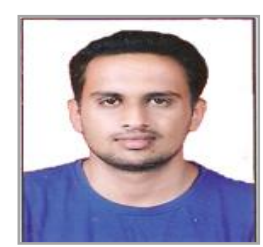

Mangesh Sanjay Yeolekar ${ }^{3}$, Pursuing Final Year in Bachelor of Mechanical Engineering degree from GES's R.H.S.C.O.E, Nashik, under the affiliation of University of Pune, Maharashtra, India

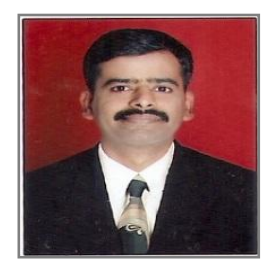

Prof. Sandip.B.Sonawane ${ }^{4}$, B.E. in Mechanical Engineering and M.E.in Heat Power (from University of Pune) Ph.D. (from IIT Bombay) 